\title{
POLLINATION BIOLOGY OF HERACLEUM SPHONDYLIUM L. (APIACEAE). THE ADVANTAGES OF BEING WHITE AND COMPACT
}

\author{
MARCIN ZYCH \\ Warsaw University Botanic Garden \\ Aleje Ujazdowskie 4, 00-478 Warszawa, Poland \\ e-mail: mzych@bot.uw.edu.pl
}

(Received: August 1, 2001. Accepted: February 11, 2002)

\begin{abstract}
Two questions were addressed in the present study: (1) What are the main pollinators of the two subspecies of $H$. sphondylium?, and (2) Do the studied plants share the pollinators' set or are they attractive for different groups of insects? The survey showed that among 40 insect taxa visiting both subspecies of $H$. sphondylium approx. only $53 \%$ carried significant pollen loads. However, the Pollinator Importance Coefficient (IC) calculated for each insect group, and based on observation of insects' abundance, within-umbel activity and pollen load revealed that only two taxa in case of $H$. s. ssp. sibiricum (Thricops nigrifrons, Eriozona syrphoides) and four in case of $H . s$. ssp. sphondylium ( $T$. nigrifrons, E. syrphoides, Meliscaeva cinctella and Arge ustulata) were truly important pollinators. Although both subspecies were visited by similar insects, H. s. ssp. sphondylium, with its characteristic compact and white umbels, was visited more frequently by Diptera and Hymenoptera, while yellow-greenish loose umbels of $H$. s. ssp. sibiricum were preferred by Coleoptera. This paper indicates that the concept of faithful pollinators may also apply to a broader spectrum of Apiaceae, usually considered primitive in terms of pollination strategies, and suggests possible ways of differentiation in two closely related taxa.
\end{abstract}

KEY WORDS: Heracleum sphondylium L., Diptera, colour morphs, pollination, pollinator importance.

\section{INTRODUCTION}

For the last decade the traditional view of plant pollination systems has been questioned with arising evidence for widespread generalisation of plant pollination strategies and opinion that the previously accepted idea of a direct link between the observed floral traits and pollinators might not be so simple (Waser et al. 1996; Johnson and Steiner 2000). As shown by different authors, plants considered specialised may be pollinated by a considerable number of taxa (Beattie 1971), and primitive species, as those of Apiaceae, could have 'faithful pollinators' (Bell 1971).

The descriptions of flower visitors of Apiaceae list numerous insects belonging from several to a few hundred taxa (Drabble and Drabble 1917, 1927; Corbet 1970; Bell 1971; Grace and Nelson 1981; Lindsey 1984; Sheppard 1991; Proctor, Yeo and Lack 1996; Dlussky 1998; Lamborn and Ollerton 2000), only for the dipteran family Tachinidae Karczewski (1967) describes 33 species observed on flowers of $H$. sphondylium.

More recent studies however reveal that flower visitors are not synonymous with pollinators. For example pollen loads and number of visits to different species of Angelica (Bell and Lindsey 1978) and H. sphondylium and H. man- tegazzianum (Grace and Nelson 1981) showed a considerable difference in pollinators' importance. Analysis of insect visitors of two American umbelliferean genera Thaspium and Zizia showed that for most pollinations (up to $75 \%$ ) only few insect species were responsible (Lindsey 1984). It is also noteworthy that in case of closely related $H$. sphondylium and $H$. mantegazzianum, growing sympatrically in a mixed population and characterised by similar pollination systems, different pollinators' assemblages were observed (Grace and Nelson 1981). It may have been caused by the difference in heights of the inflorescence. A similar situation may probably be found in other closely related taxa.

Apart of inflorescence height, flower colour and symmetry may be responsible for attracting different groups of pollinators (Faegri and van der Pijl 1979; Proctor, Yeo and Lack 1996). Usually this kind of studies are conducted on the level of genera, species or for artificial flowers (e.g. Lunau 1993; Johnson and Dafni 1998). There are very few works that focus on the consequences of intraspecific differences on the success of individuals (Herrera 1996). Such relationship was found for two colour morphs of Raphanus raphanistrum (Brassicaceae). In a mixed whiteand yellow-flowered population, individuals with yellow 
flowers were found more attractive for butterfly and hoverfly pollinators (Kay 1976). Also evidence for selection of flower colour was presented in Delphinium nelsonii (Waser and Price 1983). Further analysis of closely related taxa with different flower morphology could be useful for tracing the possible ways of evolution of features connected with sexual reproduction and subsequently to show the existing trends of species differentiation (Herrera 1996). So far no evidence on this matter has been presented for Apiaceae.

Among European species Heracleum sphondylium L. (hogweed) may serve as possible object for similar studies. Two of its subspecies (H. s. ssp. sphondylium and $H$. s. ssp. sibiricum), formerly considered separate species, differ in flower and inflorescence morphology. The former has a white corolla with flowers with elongated petals arranged on the edge of an umbel, while the later has greenish petals with no such 'edge effect' (Gawłowska 1961, Sheppard 1991). It seems possible that these floral characteristics may serve as attractants for different groups of pollinators which would create a mechanism of differentiation between the two related taxa.

In the present study I was especially interested in answering the following questions:

(1) What are the main pollinators of the two subspecies of H. sphondylium?

(2) Do the plants studied share the pollinators' set or are they rather attractive for different groups of insects?

\section{MATERIAL AND METHODS}

\section{Heracleum sphondylium $L$.}

H. sphondylium is a perennial (hemicryptophyte) (Rabotnov 1956, Sheppard 1991), not a biennial as often stated (e.g. Brummitt 1968), with cauline leaves arranged in a rosette producing erect flower stems up to $3 \mathrm{~m}$ tall. It is widespread in forests and woodland clearings, riverbanks, and tall montane-herb grasslands (Sheppard 1991). In Poland it is usually described as a common meadow species (Gawłowska 1956), growing also in thickets, on roadsides and forest fringes (Rutkowski 1998). Its geographical range includes most of the European countries, except the extreme north, parts of the Mediterranean region and some Atlantic and Mediterranean islands (Brummitt 1968; Sheppard 1991).

H. sphondylium reproduces mainly by seeds; vegetative division of root stock, although occasionally occurring, is not important (Sheppard 1991). The open, protoandrous flowers, arranged in compound umbels, are antomophilous with insects visiting flowers for pollen and nectar excluded by exposed swollen base of the style called stylopodium. Most of the flowers are actinomorphic, however the outer flowers in umbellets may be zygomorphic (Gawłowska 1956, 1961; Sheppard 1991). Umbels, depending on their order, may comprise hermaphrodite or male flowers (i.e. flowers with aborted female parts). However, the percentage of male flowers is not high and does not exceed $40 \%$ in tertiary umbels; in primary umbels hermaphrodite flowers usually constitute 100\% (Wróblewska 1992). Flower colour varies from greenish, greenish-yellow (H. s. ssp. sibiricum), to white or pinkish (H.s. ssp. sphondylium).

\section{Study site}

The observations were conducted in two sites in the same forest complex in Wigry National Park (NE Poland), the distance between the two populations was approx. 3 $\mathrm{km}$. The population of H.s. ssp. sphondylium was situated near the village Krzywe in the forest clearance approx. 50 $\mathrm{m}$ from the road Suwałki-Sejny (road no. 660), and the population of H. s. ssp. sibiricum on the border of the forest sections 133 and 134. Both grew in similar habitat conditions, along the forest road in mixed spruce-pine forest, and consisted of similar number of individuals.

\section{Field observations}

Field observations were conducted on 23-27 July of 1998. These four days represented the peak of flowering for the primary umbels, also the weather was good enough to make the observations possible. Only primary umbels with at least $50 \%$ of flowers in the male phase were chosen for observations. This restriction was implied by the fact that mainly these umbels are responsible for seed production (Sheppard 1991). The observation started at 8.30 a.m. (the first recording) and ended at 7.00 p.m. (the last capturing). The time was chosen on the basis of earlier observations revealing that before 8.00 a.m. and after 7.00 p.m. flowers of hogweed are visited by insects only occasionally.

Every day eleven rounds of observations were conducted (except $24^{\text {th }}$ July - nine rounds, observations stopped by rain; and $25^{\text {th }}$ - two rounds). Each round lasted 1 hour and comprised of three phases: random choice of an umbel, video recording, and insect capturing.

Once selected umbels were not excluded from the next round and therefore it was possible that the same umbel was observed twice or more times.

After an umbel had been selected it was stick bound to prevent it from wind-caused movements. Then for $10 \mathrm{~min}-$ utes insect activities were recorded using an $8 \mathrm{~mm}$ video camera (Sony TR-3200). The camera was set on a tripod at a distance of about $0.5 \mathrm{~m}$ from the umbel. The recording field covered the total umbel surface. 20 minutes after recording, for 10 minutes, all the insects visiting an umbel were collcted either with enthomological net (Diptera, Hymenoptera, Lepidoptera) or directly to plastic vials (Coleoptera, Hemiptera). Insects were killed with ethyl acetate and stored dry for further investigations of their pollen loads. Aphids and other small, sap sucking insects (e.g. Thysanoptera) were excluded from the analysis.

\section{Pollen loads analysis}

For investigation of pollen loads carried by insects visiting flowers of $H$. sphondylium a modified method of Grace and Nelson (1981) and Lidsey (1984) was used. An insect was put on the microscopic slide and pollen from its body was removed using a thin brush until no remaining pollen was visible. This was done under stereoscopic microscope. The pollen was then stained with a drop of acetoorceine and covered with microscopic cover glass. After that the brush was carefully cleaned so the pollen could not contaminate the next sample. Pollen samples were analysed using a light microscope. All $H$. sphondylium pollen grains from randomly selected five areas on one sample were counted. Arithmetic mean of the counts, after extrapolation, was used to calculate the pollen load of a given indi- 
vidual. ANOVA performed for the first 26 counts showed that the variance among the counts of a single sample was significantly lower than variance among the samples $(\mathrm{F}=2.073, \mathrm{P}<0.01)$, this may account on the adequacy of the method used.

\section{Measuring the pollinators importance}

Analysis of insect activities were based on video recordings. The number of visits and within-umbel activity (no. of umbellets visited) of all insect visitors were measured. This seems a reasonable measure because umbellets, with overlapping, elongated petals of the outer flowers, forming compound umbels, may in many Apiaceae act as reproductive units (Bell 1971). The importance of the insect visitors to $H$. sphondylium was calculated using a pollinator importance measure (I):

$$
\mathbf{I}_{\mathbf{x}}=\mathbf{V} \times \mathbf{U} \times \mathbf{P L} \quad[\text { Equation 1] }
$$

Where:

$I_{x}$ - importance of insect species $X$,

$\mathrm{V}-$ no. of recorded visits + no. of individuals of species $\mathrm{X}$ captured / total no. of visits recorded + total no. of individuals captured,

Table 1. Number of insect visits ${ }^{1}$ on flowers of two subspecies of $\mathrm{H}$. sphondylium and the average pollen load carried by an individual. Video - no. of individual visits recorded; Capture - no. of individuals captured; PL - pollen load shown on the relative scale $* * *>* *>$ * $>$ t (trace) $>-$ no pollen, $x$ no data. Probability $(P)$ of such distribution calculated from cumulative binomial distribution.

\begin{tabular}{|c|c|c|c|c|c|c|c|}
\hline & \multicolumn{3}{|c|}{$\begin{array}{l}\text { H. sphondylium } \\
\text { ssp. sibiricum }\end{array}$} & \multirow{2}{*}{$P$} & \multicolumn{3}{|c|}{$\begin{array}{l}\text { H. sphondylium } \\
\text { ssp. sphondylium }\end{array}$} \\
\hline & Video & Capture & PL & & Video & Capture & PL \\
\hline \multicolumn{8}{|l|}{ Diptera } \\
\hline Cheilosia sp. & 2 & 1 & $\mathrm{t}$ & ns & 3 & 0 & $\mathrm{x}$ \\
\hline Chloropodidae & 4 & 1 & - & 0.013 & 11 & 5 & - \\
\hline Episyrphus balteatus (Deg.) & 2 & 1 & - & ns & 5 & 2 & $t$ \\
\hline Eriozona syrphoides (Fall.) & 21 & 9 & $* * *$ & ns & 22 & 10 & $* * *$ \\
\hline Eurithia consobrina (Meig.) & 0 & 2 & - & ns & 2 & 2 & *** \\
\hline Fannia sp. & 0 & 0 & - & ns & 0 & 5 & - \\
\hline Fanniidae & 0 & 1 & - & $<0.005$ & 20 & 10 & - \\
\hline Ischyrosyrphus glaucius (L.) & 0 & 0 & $\mathrm{x}$ & ns & 0 & 1 & ** \\
\hline Lucilla caesar (L.) & 2 & 3 & $* *$ & ns & 5 & 2 & ** \\
\hline Meliscaeva cinctella (Zett.) & 27 & 15 & $\mathrm{t}$ & $<0.005$ & 113 & 40 & ** \\
\hline Morellia aenescens (R.-D.) & 0 & 2 & - & ns & 1 & 1 & $* * *$ \\
\hline Myathropa florea $(\mathrm{L})$. & 0 & 2 & ** & ns & 0 & 1 & ** \\
\hline Phaonia angelicae (Scop.) & 0 & 1 & ** & $<0.05$ & 1 & 9 & ** \\
\hline Platychira radicum (Fabr.) & 0 & 0 & - & ns & 0 & 1 & ** \\
\hline Sepsidae & 0 & 0 & - & $<0.005$ & 193 & 30 & - \\
\hline Syrphidae & 0 & 0 & $\mathrm{x}$ & ns & 1 & 0 & $\mathrm{x}$ \\
\hline Syrphus ribesii (L.) & 0 & 0 & $\mathrm{x}$ & ns & 0 & 1 & - \\
\hline Thricops nigrifrons (R.-D.) & 127 & 45 & ** & ns & 126 & 20 & $* * *$ \\
\hline Volucella pellucens $(\mathrm{L})$. & 0 & 2 & ** & ns & 0 & 0 & $\mathrm{x}$ \\
\hline \multicolumn{8}{|l|}{ Coleoptera } \\
\hline Dasytes sp. & 38 & 20 & ** & $<0.005$ & 9 & 9 & $t$ \\
\hline Meligethes sp. & 34 & 14 & - & $<0.005$ & 5 & 15 & - \\
\hline Mordellistena sp. & 3 & 3 & - & ns & 0 & 1 & - \\
\hline Rhagonycha fulva (Scop.) & 0 & 1 & $*$ & ns & 1 & 1 & $* *$ \\
\hline Stenurella melanura (L.) & 0 & 6 & $* *$ & ns & 1 & 2 & ** \\
\hline Strangalia maculata (Poda) & 0 & 1 & $* * *$ & ns & 0 & 0 & $\mathrm{x}$ \\
\hline Trichodes apiarus (L.) & 0 & 1 & $* *$ & ns & 0 & 0 & $\mathrm{x}$ \\
\hline \multicolumn{8}{|l|}{ Hymenoptera } \\
\hline Apoidea & 0 & 0 & $\mathrm{x}$ & ns & 2 & 0 & $\mathrm{x}$ \\
\hline Arge ustulata (L.) & 1 & 0 & - & ns & 1 & 3 & $* * *$ \\
\hline Bombus sp. & 0 & 0 & $\mathrm{x}$ & ns & 2 & 0 & $\mathrm{x}$ \\
\hline Cimbex sp. & 0 & 0 & $\mathrm{x}$ & ns & 0 & 1 & ** \\
\hline Hymenoptera & 0 & 0 & $\mathrm{x}$ & ns & 1 & 0 & $\mathrm{x}$ \\
\hline Ichneumonidae & 4 & 1 & - & ns & 7 & 4 & ** \\
\hline Macropis fulvipes (Fabr.) & 0 & 1 & - & ns & 0 & 0 & $\mathrm{x}$ \\
\hline Sphecidae & 1 & 0 & $\mathrm{x}$ & ns & 0 & 0 & $\mathrm{x}$ \\
\hline Vespidae & 0 & 0 & $\mathrm{x}$ & ns & 1 & 0 & $\mathrm{x}$ \\
\hline \multicolumn{8}{|l|}{ Hemiptera } \\
\hline Calocoris sp. & 3 & 5 & * & $<0.05$ & 0 & 0 & $\mathrm{x}$ \\
\hline Lygus sp. & 0 & 12 & $\mathrm{t}$ & ns & 4 & 6 & $* *$ \\
\hline \multicolumn{8}{|l|}{ Lepidoptera } \\
\hline Araschnia levana (L.) & 0 & 0 & - & ns & 0 & 1 & - \\
\hline Argynnis paphia (L.) & 0 & 2 & $* *$ & ns & 0 & 0 & - \\
\hline Pyralidae & 0 & 0 & $\mathrm{x}$ & ns & 1 & 1 & - \\
\hline
\end{tabular}


$\mathrm{U}$ - mean no. of umbellets visited by species $\mathrm{X}$ within an umbel / mean no. of umbellets in an average umbel in the population surveyed,

$\mathrm{PL}$ - average pollen load carried by an individual of species X.

This was then summarised for each subspecies and treated as 1.0 to obtain the pollinator importance coefficient for each insect taxon (IC).

\section{Insect identification and statistics}

Most of the insects were identified to the species level. In many cases video recordings allowed to identify the species; when this was impossible I tried to identify insects to the lowest possible rank (usually family).

All statistical calculations were performed either manually or using STATISTICA PL (StatSoft Poland, Kraków) run on PC computer.

\section{RESULTS}

During observations of flowers of H.s. ssp. sibiricum and H.s. ssp. sphondylium 152 and 184 insects were captured, respectively. During the analysis of video records 269 visits to flowers of $H$. s. ssp. sibiricum and 538 to flowers of $H$. s. ssp. sphondylium were observed. The summarised number of visits shows that the latter plant was visited significantly more frequently $(\mathrm{P}<0.005$, probability of such distribution based on cumulative binomial distribution). The list comprising 40 taxa belonging to five orders (Hymenoptera, Lepidoptera, Diptera, Hemiptera and Coleoptera) is presented in Table 1. Among them, 15 species were only occasional visitors (less than 5 visits video and capture). For both the subspecies, the highest percentage of visits belonged to Diptera ( $64 \%$ for $H$. s. ssp. sibiricum, and $89 \%$ for $H$. s. ssp. sphondylium). The least frequent visitors were Lepidoptera - only 2 visits on flowers of $H$. s. ssp. sibiricum and 3 on $H$. s. ssp. sphondylium (in both cases less than $0.5 \%$ of all visits). Also Hymenoptera were rare visitors - they accounted for only $2 \%$ of visits on $H$. s. ssp. sibiricum flowers and 3\% visits on H.s. ssp. sphondylium (Fig. 1).

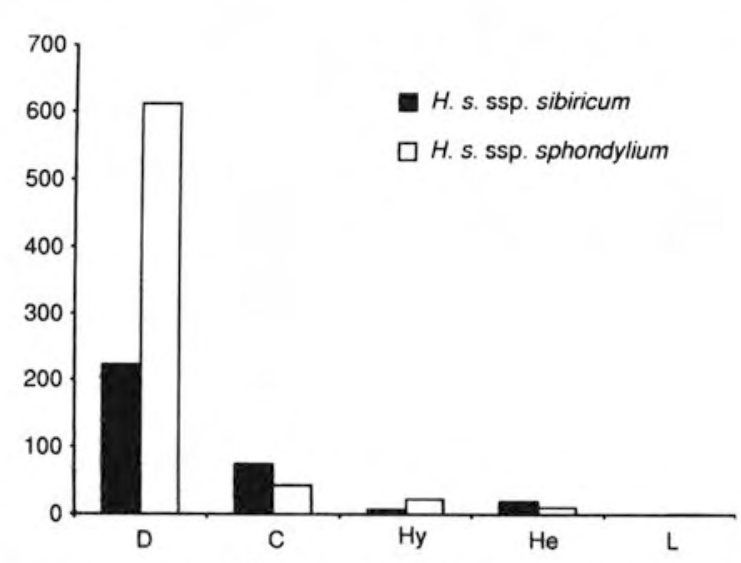

Fig. 1. No. of individuals of different orders visiting flowers of two Heracleum sphondylium subspecies (video and capture, summarised data). D - Diptera, C - Coleoptera, Hy - Hymenoptera, He - Hemiptera, L - Lepidopetra.

The most frequent visitor of $H$. s. ssp. sibiricum (video and capture) was Thricops nigrifrons (R.-D.) (Muscidae) more than $34 \%$ visits. This fly was also encountered frequently on flowers of $H$. s. ssp. sphondylium (20\% visits) in which however the small Diptera of family Sepsidae were more frequent (almost $31 \%$ visits). These were not seen on $H$. $s$. ssp. sibiricum flowers. Although quite abundant, Sepsidae were unimportant pollinators because they carried no pollen on their bodies.

For both subspecies surveyed the biggest pollen load has been found on the body of a single individual of Strangalia maculata (Poda) (Cerambycidae) captured on H. s. ssp. sibiricum. Among the most frequent visitors the biggest pollen loads were carried by individuals of Eriozona syrphoides (Fall.) (Syrphidae), Arge ustulata (L.) (Argidae), Eurithia consobrina (Meig.) (Tachinidae), Morellia aenescens (R.-D.) (Muscidae) and T. nigrifrons (Muscidae) (Table 1). Beetles of genera Dasytes (Melyridae) and Meligethes (Nitidulidae) spent most of the time on hogweed flowers, however their efficiency as pollinators was relatively small. Individuals of Dasytes carried only trace of pollen and visited on the average one umbellet in the single umbel, similarly to Meligethes that carried almost no

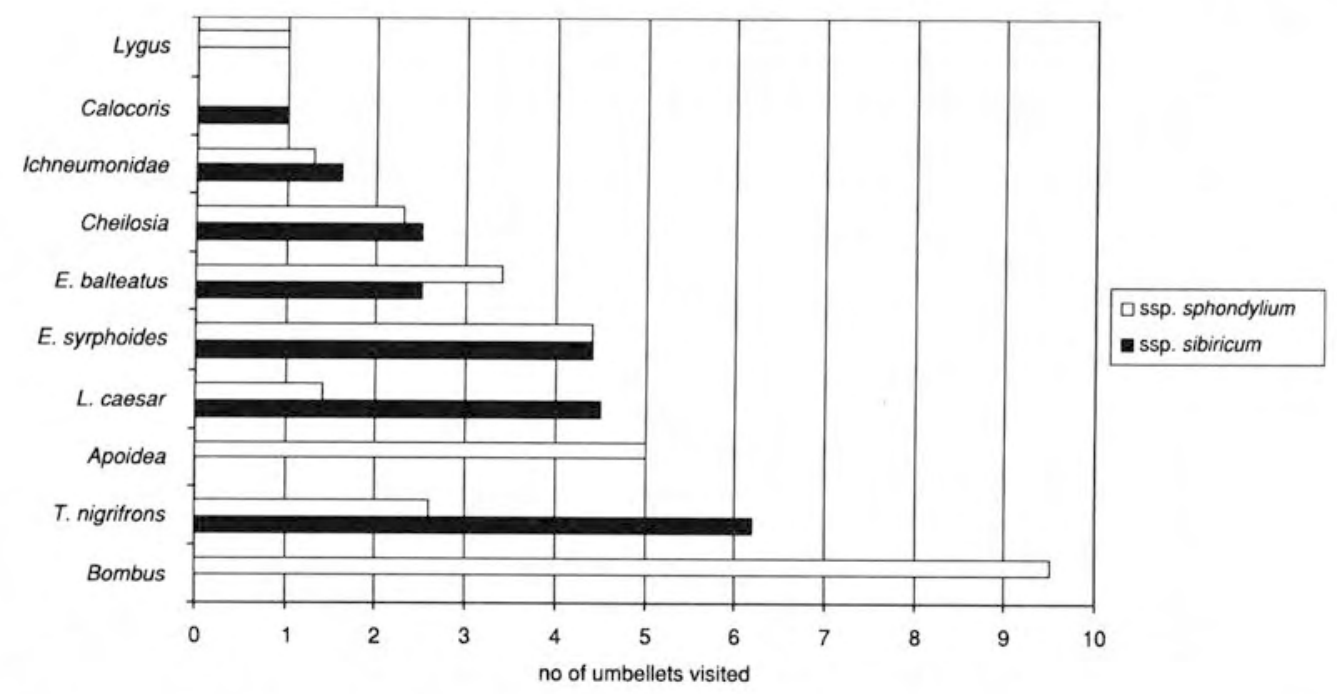

Fig. 2. The average number of umbellets of $H$. sphondylium ssp. sphondylium and $H$. sphondylium ssp. sibiricum visited by different insect taxa. 
pollen. I observed similar long visits for carnivorous Hemipteran genera Calocoris and Lygus. They also visited one umbellet on the average and carried only trace of pollen - their pollination importance was therefore small. Bumblebees (Bombus sp.) made the longest trips on an inflorescence, and visited almost $2 / 3$ of umbellets in a single umbel (Fig. 2). Unfortunately it was impossible to calculate IC for this taxon because no individual was captured. For most of the insects there was no significant difference between the length of the walking distance made on inflorescences of the two subspecies. Only for $T$. nigrifrons and $L$. caesar this difference was significant both visited approx. three times more umbellets of $H . s$. ssp. sibiricum (t-test, $\mathrm{p}<0.001$ for $T$. nigrifrons; $\mathrm{p}<0.002$ for $L$. caesar). Hoverflies $E$. syrphoides visited almost $1 / 3$ of umbellets of both subspecies (Fig. 2).

Comparison of the number of insect visits (no. of visits calculated as a sum of captures and video recordings) showed significant differences between the studied subspecies of $H$. sphondylium (Table 1; probability of such distributions calculated from binomial distribution). H. $s$. ssp. sphondylium was visited more frequently by Diptera $(\mathrm{P}<0.005)$, even when the taxa that carried no pollen were excluded, and Hymenoptera $(\mathrm{P}=0.01)$, while $H$. s. ssp. sibiricum was preferred by Coleoptera $(\mathrm{P}<0.005)$. Significant differences occurred also within the orders for individual insect taxa (Table 1).

The importance of particular vectors differed also between the studied subspecies (Fig. 3). The most important pollinators were muscid flies Thricops nigrifrons ( $\mathrm{IC}=0.74$ for ssp. sibiricum, and 0.39 for ssp. sphondylium) and hoverflies Eriozona syrphoides (IC $=0.25$ for ssp. sibiricum, and 0.39 for ssp. sphondylium). Syrphids were the most important group on $H$. s. ssp. sphondylium (IC=0.49), and less important on flowers of $H$. s. ssp. sibiricum $(\mathrm{IC}=0.25)$. The remaining 0.01 for $H$. sphondylium ssp. sibiricum accounted for coleopteran genus Dasytes. For H. sphondylium ssp. sphondylium more important were Arge ustulata (Hymenoptera; $\mathrm{IC}=0.07)$ and four other fly species $(\mathrm{IC}=0.05)$.

The mean umbellet number per one umbel necessary for calculating $\mathrm{U}$ from Equation 1 was 15.6 for $H$. s. ssp. sibiricum and 15.8 for H. s. ssp. sphondylium $(\mathrm{N}=22)$.

\section{DISCUSSION}

It is generally agreed that the number of pollinators (or list of flower visitors) is a poor measure of flower specialisation and pollinators' importance (Weiser et al. 1996; Johnson and Steiner 2000). Many authors state that the best description of pollinator importance can be achieved by direct methods, such as measuring pollen loads deposited on flower stigma by a given pollinator species (e.g. Primack and Silander 1975) or direct measures of seed set after visits of certain pollen-carrying vectors (Motten et al. 1981, Pettersson 1991, Miyake and Yahara 1998). Unfortunately, in case of plants with the so-called 'promiscuous' floral systems (Grant 1949) such as Apiaceae, the methods cited above are inadequate because it is impossible to calculate the pollinators importance index for all insect visitors - there are so many of them. It is also unsatisfactory to work only with the animal group chosen, simply based on floral syndromes (Waser et al. 1996). In many cases effective pollinators constitute only a small fraction of the total of animal species observed on the flowers of certain plant species (Lindsey 1984; Schemske and Horowitz 1984; Fishbein and Venable 1996). In such situations other indirect methods e.g. measuring of the pollen loads carried by different vectors, observations of their frequency, abundance and behaviour on the flowers may be more useful. Among them photographic methods, especially video techniques, have already been applied for studies on pollination ecology of angiosperms (Kearns and Inouye 1993). These are extremely useful for observations of species visited by many pollinating vectors - such as the umbellifers described herein. The sum of the above elements may make a useful description of pollination effectiveness and importance of certain pollinators (Lindsey 1984; Lamborn and Ollerton 2000).

Flowers of Apiaceae are generally considered primitive in terms of pollination systems. Among them genus Heracleum, and particularly $H$. sphondylium is said to be visited by many dipteran taxa (Drabble and Drabble 1917, 1927; Karczewski 1967; Grace and Nelson 1981; Sheppard 1991, Proctor, Yeo and Lack 1996). In most of the studies flower visitors were treated as pollinators (e.g. Sheppard 1991).

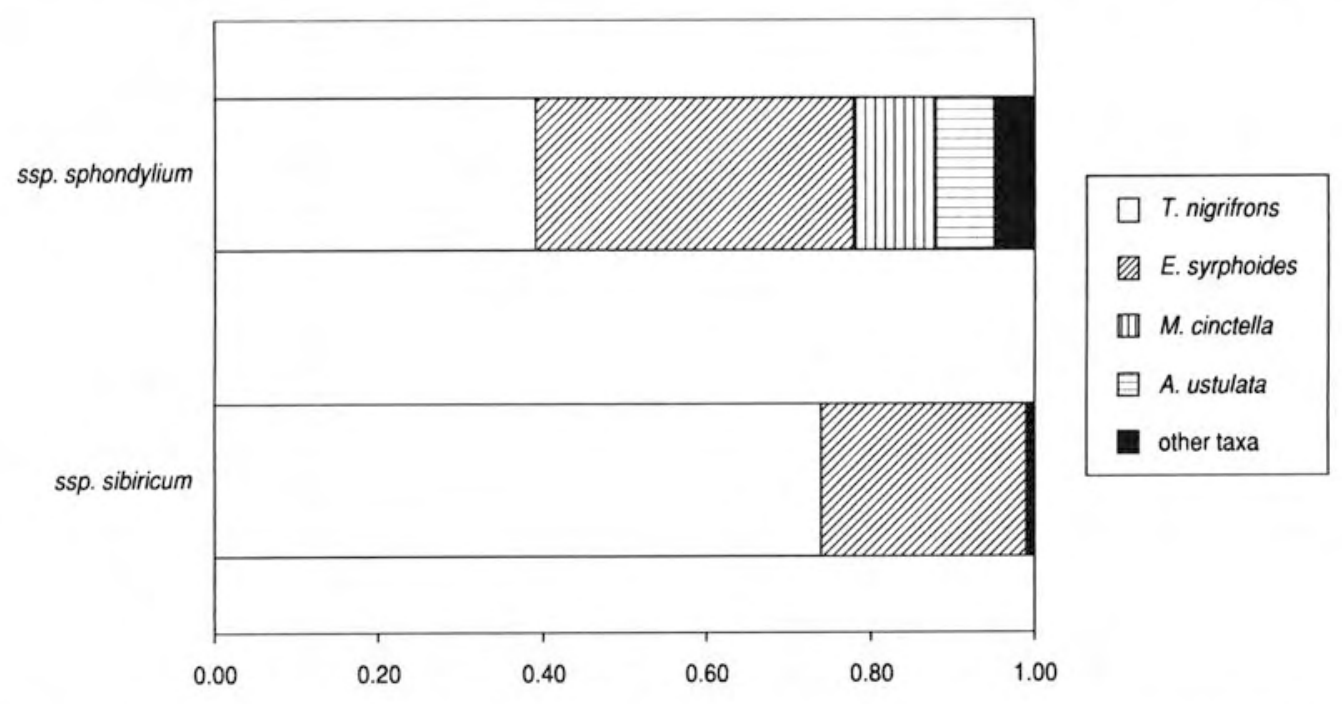

Fig. 3. Pollinator Importance Coefficient (IC) for insects carrying $H$. sphondylium pollen. For IC formula see Methods. 
However the analysis carried out by Grace and Nelson (1981) for $H$. sphondylium and $H$. mantegazzianum showed that among 80 insect taxa, captured on inflorescences of both the species, only 31 carried significant pollen loads. However these descriptions of pollinators' importance were only based on the estimated pollen loads. A more complex approach was used in studies on reproduction strategies of Angelica and three related species from among the American genera Thaspium and Zizia (Bell and Lindsey 1978; Lindsey 1984). These surveys showed that despite the broad spectrum of flower visitors, only few insect species were responsible for pollination e.g. in case of Angelica these were mainly four species of bumblebees (Bombus sp.) and other Hymenoptera (Bell and Lindsey 1978), and in case of protogynous Thaspium and Zizia - solitary bees (Lindsey 1984). Also for Daucus carota the most efficient pollinators (depending on the season) were various Diptera, Tenthredo sp. (Hymenoptera) and Rhagonycha fulva (Coleoptera) (Lamborn and Ollerton 2000). This paper reports similar trends for protoandrous $H$. sphondylium which suggests that the concept of 'faithful pollinators' of Apiaceae (Bell 1971; Bell and Lindsey 1978; Lindsey 1984) may be more common than previously expected.

In the studies of Grace and Nelson (1981) Diptera accounted for over $78 \%$ of flower visitors to $H$. sphondylium in Great Britain. In my studies this number is equally high $-80 \%$ for summarised results for both subspecies (video and capture). Not all of these were equally efficient pollen carrying vectors - the most efficient were flies $T$. nigriforns (Muscidae) and hoverflies Eriozona syrphoides, however their importance differed between the subspecies studied. The former was also observed by Grace and Nelson (1981) and was described as carrying significant pollen loads. While $T$. nigrifrons was the major pollinator for $H$. s. ssp. sibinicum, its efficiency was equal to $E$. syrphoides in case of $H$. s. ssp. sphondylium. Also the diversity of pollen-carrying vectors was higher for this taxon (this included $M$. cinctella, A. ustulata and four other flies). Other insect species, although sometimes abundant (as Meligethes sp.), or carrying large pollen loads ( $S$. maculata) were not important pollinators, either because they were incapable of carrying pollen (Meligethes sp. perhaps because of small size and behaviour on the flower) or were very rare visitors.

Many authors indicate that the existence of morphologically different forms of the same species may imply the usage of different pollinators' sets which leads to speciation (Kay 1976; Herrera 1996). However the colour is not always the only clue for different pollinator behaviour. In case of two colour morphs of Delphinium nelsonii white flowers did not posses 'nectar guides' that attracted insects and hummingbirds to blue flowers (Waser and Price 1983). Also the size of inflorescence (Brody and Mitchell 1997) and its compactness (Bell 1971) may be of great value in terms of attractiveness for pollinators. As showed in this paper, it is also true for $H$. sphondylium, because $H$. s. ssp. sphondylium, with its showy and compact inflorescences, was significantly more attractive for Diptera and Hymenoptera. This is consistent with the general assumption that Diptera and Hymenoptera are more attracted by white than greenish flowers, whereas Coleoptera generally prefer flowers with dull colours (brownish and greenish)
(Proctor, Yeo and Lack 1996). Surprisingly, most of pollinators made similarly long visits, only $T$. nigrifrons and $L$. caesar visited three times more umbellets of ssp. sibiricum (Hymenoptera visited more umbellets of ssp. sphondylium, but the visits were so rare that it was impossible to use any statistical test to confirm this observation). Perhaps this behaviour may be explained by the tendency to avoid the predators (e.g. wasps visiting umbels for pray) - dark flies are more visible on white than on dull green flowers.

Apart from colours, flower scents may also play a major role in pollination and may serve as other possible explanation of different pollinators' sets; Tollsten and Øvstedal (1994), who studied three populations of the umbelliferean Conopodium majus, showed significant differences in flower scent chemistry among them. They concluded that it might reflect "an ecotypic response to local faunae of pollinators". It may therefore mean that also in case of $\mathrm{H}$. sphondylium floral features, not studied in the present paper, acting on insects' behaviour are more subtle and need further studies.

Although for both subspecies the most important pollinators were Diptera (especially $T$. nigrifrons and $E$. syrphoides) results of this study may indicate specialisation towards some particular group of insects, as the most efficient on $H$. s. ssp. sphondylium were syrphid flies. Perhaps also Hymenoptera played an important role in the evolution of its pollination system. As most of montane forms of H. sphondylium and other European montane Heracleum have white zygomorphic flowers (Brummitt 1968), one possible explanation is that this particular trait could have been important in attracting high-elevation pollinators such as bumblebees etc. To confirm this assumption further studies are necessary, as it is impossible to state whether this trend is constant in consecutive season; it was postulated by Waser et al. (1996) and showed by Herrera (1988, 1995, 1996) for Lamiaceae, Fishbein and Venable (1996) for Asclepias, and Lambert and Ollerton (2000) for Daucus carota, that the key pollinators' abundance may vary between seasons. It seems also plausible that, possibly because of the changing geographical range, this situation is just a result of an ancient adaptative 'peak', common for many Apiaceae, that no longer has a great functional importance to this species (Bell 1971) - similarly to the significance of the dark central floret found in Daucus carota (Lamborn and Ollerton 2000). Earlier studies for Poland (Gawłowska 1956, 1957) restrict the distribution of $H$. s. ssp. sphondylium to the southern part, and $H$. s. ssp. sibiricum to the northern part of the country. However my observations show that both taxa can be found in different regions. Perhaps in places of origin of the two forms, locally important insect groups existed that favoured certain floral features and the selective pressure led to nowadays existing taxa.

\section{ACKNOWLEDGEMENTS}

I would like to thank Prof. A. Draber-Mońko, Dr. A. Krzysztofiak, and Dr P. Tykarski for insect identification, and Wigry National Park for the possibility of conducting field research. Krzysztof Spalik made valuable comments on the manuscript, and Ingeborga Jarzyna helped with statistics. This work would have not been done without con- 
stant support from Hanna Werblan-Jakubiec. The study was supported financially by Grant BW-1420/98/5 from Faculty of Biology, Warsaw University.

\section{LITERATURE CITED}

BEATTIE A.J. 1971. Pollination mechanisms in Viola. New Phytol. 70: 343-360.

BELL C.R., LINDSEY A.H. 1978. The umbel as a reproductive unit in the Apiaceae. In: Actes du 2eme Symposium International sur les Ombelliferes, Contributions pluridisciplinaires a la Systematique, pp. 739-747. Perpignan, France.

BELL C.R. 1971. Breeding systems and floral biology of the Umbelliferae or evidence for specialization in unspecialized flowers. In: The Biology and Chemistry of the Umbelliferae, V.H. Heywood (ed.) pp 93-107. Academic Press, London.

BRODY A.K., MITCHELL R.J. 1997. Effects of experimental manipulation of inflorescence size on pollination and pre-dispersal seed predation in the hummingbird-pollinated plant Ipomopsis aggregata. Oecologia 110: 86-93.

BRUMMITT R.K. 1968. Heracleum L. In: Flora Europaea vol. 2; 364-366. T.G. Tutin et al. (eds.). Cambridge University Press, Cambridge.

CORBET S.A. 1970. Insects on hogweed flowers: a suggestion for a student project. J. Biol. Edu. 4: 133-143.

DLUSSKY G.M. 1998. Mekhanismy konkurentsii za opylitieley u kupyria (Anthriscus sylvestris) i snyti (Aegopodium podagraria) (Apiaceae). Zhurnal Obshchey Biologii 59: 24-44. (in Russian).

DRABBLE E., DRABBLE H. 1917. The syrphid visitors to certain flowers. New Phytol. 16: 105-109.

DRABBLE E., DRABBLE H. 1927. Some flowers and their dipteran visitors. New Phytol, 26: 115-123.

FAEGRI K., VAN DER PIJL L. 1979. The Principles of Pollination Ecology, $2^{\text {nd }}$ ed. Pergamon Press, Oxford.

FISHBEIN M., VENABLE D.L. 1996. Diversity and temporal change in the effective pollinators of Asclepias tuberosa. Ecology 77: 1061-1073.

GAWŁOWSKA M. 1956. Heracleum sphondylium L. i Heracleum sibiricum L. na ziemiach polskich. Diss. Pharm. 7: 141164. (in Polish)

GAWŁOWSKA M. 1957. Badania nad rozmieszczeniem Heracleum sphondylium L. i $H$. sibiricum L. w Polsce. Fragm. Flor. Geobot. 3: 61-68. (in Polish)

GAWŁOWSKA M. 1961. Systematyka wewnątrzgatunkowa $\mathrm{He}$ racleum sphondylium L. i Heracleum sibiricum L., występujących w Polsce i krajach sąsiednich. Fragm. Flor. Geobot. 7: 139. (in Polish)

GRACE J., NELSON M. 1981. Insects and their pollen loads at a hybrid Heracleum site. New Phytol. 87: 413-423.

GRANT V. 1949. Pollination systems as isolating mechanisms in angiosperms. Evolution 3: 82-97.

HERRERA C.M. 1988. Variation in mutualism: the spatio-temporal mosaic of pollinator assemblage. Biol. J. Linn. Soc. 35: 95-125.

HERRERA C.M. 1995. Microclimate and individual variation in pollinators: flowering plants are more than their flowers. Ecology 76: 1516-1524.

HERRERA C.M. 1996. Floral traits and plant adaptation to insect pollinators: a devil's advocate approach. In: Floral Biology. Studies on Floral Evolution in Animal-Pollinated Plants, D.G. Lloyd and S.C. Barrett (eds.), pp. 65-87. Chapman and Hall, New York.
JOHNSON S.D., DAFNI A. 1998. Response of bee-flies to the shape and pattern of model flowers: implications for floral evolution in a Mediterranean herb. Functional Ecol. 12: 289297.

JOHNSON S.D., STEINER K.E. 2000. Generalization versus specialization in plant pollination systems. TREE 15: 140-143.

KARCZEWSKI J. 1967. Obserwacje nad muchówkami (Diptera) z rodzin Tachinidae i Calliphoridae odwiedzającymi kwiaty. Fragm. Faun. 13: 407-484. (in Polish)

KAY Q.O.N. 1976. Preferential pollination of yellow-flowered morphs of Raphanus raphanistrum by Pieris and Eristalis spp. Nature 261: 230-232.

KEARNS C.A., INOUYE D.W. 1993. Techniques for pollination biologists. University Press of Colorado, Niwot.

LAMBORN E., OLLERTON J. 2000. Experimental assessment of the functional morphology of inflorescence of Daucus carota (Apiaceae): testing the 'fly catcher effect'. Funct. Ecol. 14: 445-454.

LINDSEY A.H. 1984. Reproductive biology of Apiaceae. I. Floral visitors to Thaspium and Zizia and their importance in pollination. Am. J. Bot. 71: 375-387.

LUNAU K. 1993. Interspecific diversity and uniformity of flower colour patterns as cues for learned discrimination and innate detection of flowers. Experientia 49: 1002-1010.

MIYAKE T., YAHARA T. 1998. Why does the flower of Lonicera japonica open at dusk. Can. J. Bot. 76: 1806-1811.

MOTTEN A.F., CAMPBELL D.R., ALEXANDER D.E., MILLER H.L. 1981. Pollination effectiveness of specialist and generalist visitors to a North Carolina population of Claytonia virginica. Ecology 62: 1278-1287.

PETTERSSON M.W. 1991. Pollination by a guild of fluctuating moth populations: option for unspecialization in Silene vulgaris. J. Ecol. 79: 591-604.

PRIMACK R., SILANDER J.A. 1975. Measuring the relative importance of different pollinators to plants. Nature 255: 143-144 .

PROCTOR M., YEO P., LACK A. 1996. Natural History of Pollination. Harper Collins Publishers, London.

RABOTNOV T.A. 1956. O zhiznennom tzykle borshchevika sibirskovo (Heracleum sibiricum L.). Bulletin Moskovskovo Obshchestva Ispitatieley Prirody 61: 73-81. (in Russian)

RUTKOWSKI L. 1998. Klucz do oznaczania roślin naczyniowych Polski niżowej. Wydawnictwo Naukowe PWN, Warszawa. (in Polish)

SCHEMSKE D.W., HORVITZ C.C. 1984. Variation among floral visitors in pollination ability: a precondition for mutualism specialization. Science 155: 519-521.

SHEPPARD A. W. 1991. Biological flora of the British Isles: $\mathrm{He}$ racleum sphondylium L. J. Ecol. 79: 235-258.

TOLLSTEN L., ØVSTEDAL D.O. 1994. Differentiation in floral scent chemistry among populations of Conopodium majus (Apiaceae). Nord. J. Bot. 14: 361-367.

WASER N.M., CHITTKA L., PRICE M.V., WILLIAMS N.M and OLLERTON J. 1996. Generalization in pollination systems, and why it matters. Ecology 77: 1043-1060.

WASER N.M., PRICE M.V. 1983. Pollination behaviour and natural selection for flower colour in Delphinium nelsonii. Nature 302: 422-424.

WRÓBLEWSKA A. 1992. Kwitnienie i pożytek pyłkowy wybranych gatunków z rodziny baldaszkowatych - Umbelliferae Juss. (Apiaceae Lindl.) w okolicach Lublina. Part I. Biologia i obfitość kwiatnienia. Acta Agrobot. 45: 5-24. (in Polish) 
BIOLOGIA ZAPYLANIA HERACLEUM SPHONDYLIUM L. (APIACEAE): O WYŻSZOŚCI BIAŁYCH KWIATÓW I ZWARTYCH KWIATOSTANÓW

\section{STRESZCZENIE}

W niniejszej pracy postawiono dwa pytania: (1) Jakie owady zapylają kwiaty dwóch gatunków $H$. sphondylium?, oraz (2) Czy badane rośliny posiadają takie same zespoły owadów zapylających, czy może są atrakcyjne dla różnych owadów? Badania wykazały, że spośród 40 taksonów owadów odwiedzających obydwa podgatunki barszczu zwyczajnego, zaledwie około 53\% przenosiło znaczące ładunki pyłku. Obliczony dla każdej grupy owadów współczynnik wagi zapylaczy (Pollinator Importance Coefficient), oparty na obserwacjach aktywności owadów oraz przenoszonych ładunkach pyłku, ujawnił, że tylko dwa gatunki w przypadku H. s. ssp. sibiricum (Thricops nigrifrons, Eriozona syrphoides) oraz cztery w przypadku $H$. s. ssp. sphondylium (T. nigrifrons, E. syrphoides, Meliscaeva cinctella oraz Arge ustulata) są rzeczywiście odpowiedzialne za zapylanie. Mimo, że oba badane podgatunki były odwiedzane przez zbliżone zespoły zapylaczy, podgatunek nominatywny, o charakterystycznych białych i zwartych baldachach, był odwiedzany częściej przez muchówki i błonkówki, natomiast luźne zielonkawe kwiatostany podgatunku syberyjskiego częściej odwiedzały chrząszcze. Praca wskazuje, że koncepcja wiernych zapylaczy może także odnosić się do szerszego spektrum baldaszkowatych (Apiaceae), uważanych zwykle za rośliny prymitywne pod wzglẹdem systemów zapylania, oraz sugeruje możliwe drogi różnicowania się dwóch blisko spokrewnionych taksonów.

SŁOWA KLUCZOWE: Heracleum sphondylium L., Diptera, morfy barwne, zapylanie, waga zapylaczy. 